\title{
THE ROLE OF MANAGEMENT DECISIONS IN EXPLAINING FIRM MARKET EXIT
}

\author{
Petra Došenović Bonča, Nina Ponikvar, Ksenja Pušnik, \\ Maks Tajnikar
}

\section{Introduction}

In this paper we focus on the importance of including the decisions made by the firm's management in the factors that explain firm market exit. In so doing, we acknowledge both theoretical and empirical findings regarding the wide array of firm market exit determinants that include also the impact of the firm's managers and their decisions that may in many instances even be the decisive cause of the firm's market exit. Our research is based on the premise that the consequences of decisions of the firm's management are reflected directly in the firm's technical and cost efficiency levels. Namely, it is precisely the responsibility of managers to make decisions about the quantity of employed production inputs and such input combinations that minimise the long-run costs of production. We hypothesise that wrong decisions of managers regarding input-output combinations always result in inferior technical and/or cost efficiency and that both technical efficiency and cost efficiency are important firm market exit determinants. To test our hypotheses we identify the set of factors impacting firm market exit and focus on the impact of technical and cost efficiency.

Furthermore, we assume that in differing macroeconomic environments different decisions of the firm's management prove as decisive drivers of firm market exit. In our analysis we distinguish between decisions of managers that impact only the quantities of employed inputs in relation to produced quantities of outputs, i.e. decisions relevant for attaining the firm's technical efficiency, and decisions of managers about employed input combinations that impact the firm's level of cost efficiency. In making decisions from the first set managers are concerned only with the technical aspects of production, in making decisions from the second set the managers take into consideration both technical aspects of production and input prices. It is because of this distinction that we investigate separately technical efficiency and cost efficiency as determinants of firm market exit. This is also why we study whether the importance of decisions that are relevant for attaining technical efficiency and decisions that contribute to cost efficiency for firm market exit depend on the macroeconomic environment of the analysed firms. We do so because we hypothesise that the characteristics of the macroeconomic environment influence the impact of technical and cost efficiency on firm market exit. Such an analysis reveals which types of managerial decisions are relevant for firm market exit in differing macroeconomic environments.

In order to analyse the abovementioned issues, we develop an empirical model of firm market exit based on a neoclassical theory of the firm [40] and contributions of the existing body of literature in this field. We thus specify several non-nested microeconomic models of firm market exit. To differentiate between those factors that can be influenced by firm management and those factors that are considered non-discretionary, our categorisation of explanatory variables includes four groups, i.e. internal, external, demographic and environmental factors. The specifications of models differ in their selection of variables representing individual groups of factors and in the way these variables are measured. The internal factors group includes the above discussed decisions of managers that are the main focus of this paper and are proxied by technical and cost efficiency measures that are estimated using parametric stochastic frontier analysis. Models of firm market exit are estimated using a logistic regression for rare events [35], based on a panel of the population of Slovenian firms. To identify the 
explanatory power of estimated models we use the classification test, the Bayesian information criterion and an artificial model nesting test. Microeconomic models of firm market exit are estimated for two periods in which Slovenian macroeconomic conditions differed significantly. The first period refers to years from 1995 to 2000 and the second to years from 2000 to 2005. Even though the selection of the two periods was partly influenced by data availability it was mostly determined by the key characteristics of the two studied periods. The 1995-2000 period represents the second phase of Slovenia's transition to a market economy when the transition process still imposed tight macroeconomic conditions. In this period neither liberalisation nor privatisation processes were completed but the economy had stabilised after initial transition shocks that included gaining political independence and emerging as an independent country. In the 1995-2000 period liberalisation and privatisation processes temporarily stopped. Concurrently the beginning of this first studied period marks the departure from the turbulent onset of transition when neither the macroeconomic conditions nor the legal environment enabled an objective identification of firm market exit factors [52]. Considering that the first studied period marks the completion of transition the second studied period from 2000 to 2005 represents the period when the Slovenian economy may be considered a consolidated market economy. Ownership structures and market institutions that formed in this period remained characteristic of the Slovenian economy for the entire first decade of the 21st century. At the same time the studied second time period completes before the start of overheating of the Slovenian economy that contributed to the great financial crisis in 2008. The selected two periods are thus different enough so that the impact of differing macroeconomic environments can be considered as relevant in explaining firm market exit. At the same time, the selected periods can be considered as "normal" so that the obtained results can be generalised and not influenced by specific economic conditions created by severe economic crises.

The paper contributes to the existing body of empirical firm market exit literature by estimating non-nested microeconomic models of the firm and selecting the ideal model specification by using the classification test, the Bayesian information criterion and an artificial model nesting test. Further, we introduce a new classification of firm market exit factors, i.e. internal, external, demographic and environmental factors. Among these factors the focus is on technical and cost efficiency measures that directly reflect the decisions made by the firm's management. As such, the paper contributes to the relatively small body of research investigating the impact of the decisions made by managers on firm market exit. An advantage of this paper is that the analysis of the impact of efficiency and other factors on firm market exit is based on the population of Slovenian firms regardless of their industry membership. In addition, the impact of market exit factors is investigated for two periods, allowing us to study differences in the impact of decisions made by managers in differing macroeconomic conditions. Moreover, our study is one of the few studies dealing with business failure and market exit issues in Slovenia.

\section{Literature Review}

There is a vast body of empirical literature investigating market exit factors that is based on various theories from economics, business sciences and entrepreneurship, which are relevant to understanding firm market exit. These relevant theories include the transaction cost theory [19], [61], the neoclassical theory of the firm [40], the theory of industrial organisation [5] and the dynamic growth theory consisting of Gibrat's Law [30], the passive learning theory [32], [33], the active learning theory [24], the life cycle theory [16], Schumpeter's theory of innovation [51] and the resource-based theory of the firm [42], [6].

In existing empirical studies different authors highlight and investigate diverse determinants of firm market exit. The most common determinant included in empirical research is the firm's financial operations. Foreman [26], for example, explains, when studying US local telecommunication, which firms fail within two years by considering certain financial ratios such as earnings per share, return on assets, retained earnings to assets, total debt proportion, and working capital to sales. Pompe and Bilderbeek [45] find that virtually every ratio category (profitability, activity, liquidity, and solvency ratios) has some predictive power with regard to bankruptcy. Certain ratios 
perform similarly with different populations. Opler and Titman [39] find that a firm's capital structure must also be considered as a factor in the announcement of bankruptcy. Analysing German private and public corporations, Köke [36] finds that firms are more likely to fail when financial performance is generally poor. A positive effect of the leverage variable on the likelihood of exit was found by Fotopoulos and Louri [27].

A negative relationship between firm size and the likelihood of exit was found by Brüderl and Schüssler [12], Shleifer and Vishny [52], Dunne and Hughes [23], Audretch and Mahmood [4] and Köke [36]. The age of a firm is also considered one of the key firm exit determinants. The general consensus of empirical studies examining the impact of age on exit is that (after infancy) the likelihood of exit declines with age [13], [28], [60], [58], [38], [55]. Studies also show that firm survival is linked not only to a firm's size at the time of its establishment [43] but also to the growth achieved in the period closely following the firm's establishment [43], [36], [26], [14]. Empirical support can also be found for a negative relationship between market growth and firms' exit rates. However, there is also evidence to the contrary [56].

Since in this paper we focus on the decisions of managers regarding input-output combinations as a factor of firm market exit and assume that such decisions can be assessed by firm technical and cost efficiency, those empirical contributions that include firm efficiency and macroeconomic characteristics in the range of market exit factors are of particular interest to us.

An efficiency measure obtained by data envelopment analysis (DEA) was introduced as a quality of management measure in the model predicting the failure of banks. Their contributions marked the beginning of intense research efforts to link efficiency to bank failure. Several authors [7], [62], [44], [17], [34], [41], [46] confirm that technical efficiency significantly differs between non-successful and successful banks and that these differences are evident a few years prior to failure. Another group of authors employ either DEA or Stochastic Frontier Analysis (SFA) efficiency measures as regressor in the probability function of a bank market exit [7], [59]. Most studies confirm the positive impact of technical inefficiency on the probability of banks suffering a business failure. Wheelock and Wilson [59] arrived at the same conclusion for the link between cost efficiency and the business failure of US banks.

In the past few years, research into the impact of efficiency on market exit has also extended to non-banking sectors. Becchetti and Sierra [8] report a significant positive impact of the SFA technical efficiency of manufacturing firms in Italy in the 1989-1997 period on the probability of firm survival. Similar results, but based on DEA technical efficiency measures, were obtained by Tsionas and Papadogonas [56] for a sample of 3,404 manufacturing firms in Greece, Psillaki, Tsolas and Margaritas [47] for a sample of French firms in the textile and research industries and Pušnik and Tajnikar [49] for a sample of small firms in Slovenia. Cost efficiency as a variable in the market exit prediction model in non-financial sectors has to our knowledge only been used by Pušnik and Tajnikar [49], showing that both DEA and SFA technical and cost inefficiency measures hold predictive power concerning market exit.

For our research also existing empirical contributions investigating the role of the business environment in firm market exit are of particular relevance. Contributions that examine environmental characteristics as determinants of a firm's market exit show that the probability of a firm's market exit increases with the uncertainty of the legal and regulatory environment [22], [26], [10], instability of the macroeconomic environment [21], [3], [9], [10], unexpected macroeconomic developments [22], a low level of economic activity [37], globalisation and foreign direct investments [20], [31], [63] and is also impacted by the location of the firm [59], [49]. Research on the impact of the firm's industry membership on market exit yields mixed results. Cefis and Marsili [14] show that firms from high-tech industries have the greatest probability of survival. On the contrary, Phillips and Kirchhoff [43] do not find significant differences in firm survival rates between industries.

\section{General Model of Firm Market Exit}

Following theory and empirical evidence regarding firm market exit we assume that a general firm market exit model includes four groups of factors:

$$
M E=f(I N, E X, D E, E N),
$$


where $I N$ denotes the group of internal market exit factors, $E X$ the group of external market exit factors, $D E$ the group of firms' demographic factors, while $E N$ denotes environmental factors. Market exit (ME) describes liquidation of the firm due to a business failure, the deliberate termination of business activities or as a result of a merger, acquisition or takeover.

The group of internal factors includes those firm characteristics that affect firm costs through the employment of inputs and can be directly influenced by firm management. Namely, according to the microeconomic theory of the firm [40] finding a proper combination of inputs for the firm to achieve equilibrium is the task of the firm's management. It is thus management's role to select those techniques that enable the firm to maximise its technical efficiency and to take input prices into consideration when choosing such a combination of inputs that results in allocative and cost efficiency [25], [29]. To attain allocative and cost efficiency the firm's management varies the quantity of all inputs. These management decisions about input use thus shape the firm's longrun equilibrium at a minimal average cost. External factors define the firm's position in the market and primarily influence the firm's revenues. These factors impact the firm's market exit through market prices and output quantities sold. The achieved market prices and quantities sold depend on market competition. The firm's management can thus only affect them to a limited extent and has to make decisions within limitations imposed by the market. External factors therefore cannot directly and wholly reflect the quality of a firm's management as they are conditional on market characteristics. This is why they mostly impact revenues. Actually, they impact the firm's profitability considering that internal factors control for the firm's cost level. Demographic factors are those characteristics of a firm which have their origin in the past and are a result of past decisions of firm management and past market and environmental characteristics. Consequently, demographic factors can no longer be influenced by firm management and market characteristics at the time the firm's market exit is observed. Environmental factors reflect the firm's economic, legal, political, technological and social environments.

We test two main hypotheses to satisfy the aim of this paper. First, we hypothesise that a technically and/or cost inefficient firm is more likely to exit the market. Second, technical efficiency is hypothesised to have a different effect on firm market exit compared to cost efficiency in differing macroeconomic environments.

Besides efficiency and the macroeconomic environment, the specification of our model (eq. 1) also includes other market exit factors that have been proposed by the empirical studies mentioned above and are theoretically supported to a smaller or larger extent. This is why the four groups of factors in our model also include those factors that are not directly referred to in our research hypotheses, but are important for the model to encompass all relevant firm market exit factors.

\section{Data and Methodology}

The primary data source for our study is the database of firms' financial statements collected by the Agency of the Republic of Slovenia for Public Legal Records and Related Services, which covers the whole population of Slovenian firms for the 1995-2005 period. We narrowed the dataset by excluding firms for which an industry was not defined, firms with zero employees, firms with a negative value of equity or with zero sales revenues, and firms with zero assets or zero fixed assets. We further narrowed the datasets by excluding firms with missing values in our panel. We argue that, given the purpose of our analysis, such an approach to dealing with missing values is more appropriate than other more arbitrary methods such as imputation. Further, the disadvantages of this approach do not impact our results due to the large number of firms in our database.

We split the analysed period into two panel datasets that represent differing macroeconomic conditions. The first panel represents the 1995-2000 period characterised by tight macroeconomic conditions and the second panel is based on the 2000-2005 period of a consolidated market economy. The first panel comprises data on 16,121 firms and 80,605 observations and the second panel data on 17,405 firms and 87,520 observations. Firms in both panel datasets are divided into two mutually exclusive groups, i.e. exit and non-exit firms. In the observed period of six years, exit firms are those that were in business in the first five years of the analysed period and had closed their operations, thereby exiting the 
market in the sixth year of the analysed period (2000 for the first panel and 2005 for the second panel). Non-exit firms are those that were in business for the whole six-year period. Both panels are unbalanced in favour of non-exit firms. Namely, in 2000 there were 2.48 percent of exit firms and in 2005 their share amounted to 2.19 percent. The use of unbalanced panels distinguishes our research from other studies adopting a balanced-sampling approach [8], [11].

For both analysed periods we proposed different empirical firm market exit specifications, all following the structure of the general model from equation 1. The empirical specifications thus follow the same classification of the market exit factors as the general model. Different specifications were used so that we could test our hypotheses. Namely, empirical specifications differ in the sets of internal and external factors but include the same demographic and environmental factors. More specifically, two different sets of internal factors and two different sets of external factors are included in the suggested empirical specifications. Empirical models that are created in this way from the general model of firm market exit stem from different theoretical frameworks. Due to the theoretically based variation in the sets of factors we have to consider the proposed models as non-nested models when selecting the most appropriate, i.e. ideal model for explaining firm market exit in Slovenia. We follow the model selection approach instead of the hypothesis testing approach. In the model selection approach, each competing model is evaluated by means of a numerical criterion: for a given sample observation, the procedure consists of selecting the model that optimises the chosen criterion. When using such an approach models with different specifications can be selected as the most appropriate for two different time periods.

The factors proposed by different theories as being relevant to market exit vary. In empirical research the most notable differences can be found in the selection of the array of external and internal factors. This is why for each of the two investigated periods our empirical specifications are obtained by keeping demographic and environmental factors unchanged, while testing two different sets of external factors and two different sets of internal factors. Further, the selection of a particular factor within individual sets of factors may differ between the two studied periods due to the model selection approach.

For both periods and all empirical specifications of the model, the dependent variable $(M E)$ is defined in the same way as a binary variable with a value of 1 for exit firms and a value of 0 for non-exit firms.

The first set of internal factors includes longterm and short-term internal factors. Measures of technical and cost efficiency are regarded as long-term factors and asset turnover indices as short-term internal market exit factors. Asset turnover indices (INATI) included in the first set of internal factors are days sales outstanding (INDSO), days payables outstanding (INDPO), price of debt (INDP) and days inventory in stock (INDIS). Cost (INCE) and technical efficiency (INTE) measures are obtained by Stochastic Frontier Analysis using the number of employees and the value of fixed assets as inputs, the value of business revenues as an output measure and annual gross wages per employee and the sum of depreciation and costs of financing relative to the sum of fixed assets and inventory as factor prices [48].

In the second set of internal factors shortterm internal factors remain unchanged, while labour productivity measured as the ratio between business revenues and the number of full-time equivalents (INLP), capacity utilisation as a ratio between business revenues and the value of fixed assets (INCU), the ratio between firm cost and its business revenues (INCTR), average monthly wage (INW) and price of capital approximated by the ratio between the sum of depreciation and cost of financing on one hand and total liabilities of the firm on the other hand (INPC) are included as long-term internal factors as an alternative to measures of technical and cost efficiency.

The first set of external factors also includes long-term and short-term factors. Long-term factors are represented by a set of dummy variables reflecting a firm's position in its industry and the industry's position in the whole economy. A set of dummies is obtained based on a comparison of the firm's and industry's wage and profit rates and a comparison of the industry's and economy's wage and profit rates. Such comparisons enable us to divide the analysed firms into 16 groups (EXD16) [see 54]. A firm's liquidity measured by the quick ratio $(E X Q R)$ is used as a short-term external factor. 
The second set of external factors differs from the first one in the selection of the long-term external factors. The set of dummy variables is replaced by variables reflecting the firm's longterm market position that have an impact on the firm's generated revenues. These variables include return ratios $(E X R R)$ (either return on equity $(E X R O E)$ or return on assets $(E X R O A)$ ), and profitability ratios (EXPR) (either relative break-even point, defined as the ratio between firm's actual revenues and its revenues at the break-even point $(E X B E P)$ or return on sales (EXROS)).

All empirical model specifications include the same demographic and environmental factors. Demographic factors are represented by the firm's financial leverage (DEFL) and firm size (DESIZE) measured either in terms of the value of revenues (DESIZE1) or with the value of a firm's fixed assets (DESIZE2). Environmental factors include industry (ENNACE2) and a firm's region (ENREG), included as two sets of dummy variables.

To eliminate the impact of annual changes in price levels and/or to control for industry membership, some of the independent variables are defined in terms of the deviation of the variable from the industry average, where industry is defined according to the 2-digit NACE classification of industries. Further, we estimate the 5-year trend of independent variables and use the trend regression coefficient values (see [2]) instead of annual values of independent variables to eliminate the collinearity between the values of selected variables in consequential years.

For both periods all empirical firm market exit models were assessed by the cross-sectional binominal logistic regression for rare events data of King and Zeng [35], which eliminates the impact of sample size and/or rare events on estimates of coefficients and the probability of firm exit. In choosing the ideal model specification for both of the investigated time periods we use second-degree empiricism, which represents a selection from among so-called non-nested models. The choice of alternative models was based upon a classification test, Akaike's [1] information criterion (AIC), Bayes' information criterion (BIC) [50], an artificial model nesting test, Vuong's [57] parametric distribution-free test for non-nested models and Clark's [18] nonparametric distribution-free test for non-nested models.

\section{Results}

Following the model selection approach using the above described criteria we selected the ideal model for explaining the market exit of firms in Slovenia. The model selection is shown in Figure 1, depicting that the ideal model to be used for analysing market exit is described by Alternative 2. The model under Alternative 2 includes technical and cost efficiency measures as long-term internal firm market exit factors and financial return and profitability ratios as long-term external firm market exit factors. The model with the financial return and profitability ratios as long-term external firm market exit factors was selected because it performs better than the model using the firm's relative position in its industry and the industry's position within the whole economy. Similarly, technical and cost efficiency measures are included because the comparison of alternative models that differ in the definition of long-term internal factors shows that the model with efficiency measures outperforms its counterpart including financial indicators. This result of the model selection process implies that the technical and cost efficiency measures are superior to the standard financial ratios that are widely used to capture the internal factors influencing firm market exit.

The ideal model under Alternative 2 includes technical and cost efficiency measures as long-term internal firm market exit factors and financial return and profitability ratios as long-term external firm market exit factors. This ideal model is used to study the market exit determinants for the case of firms in Slovenia in differing macroeconomic conditions. This means that we employ it to investigate firm market exit in the 1995-2000 and 2000-2005 periods. However, the empirical specifications of the ideal model for the two periods differ in the definition of some variables reflecting return and profitability. Namely, for the 19952000 period return is measured by the return on equity $(E X R O E)$ and profitability by the relative break-even point $(E X B E P)$, while for the 2000-2005 period we use the return on assets (EXROA) and the return on sales (EXROS) as return and profitability measures. Further, size is measured differently in the two periods. In the first period size is defined in terms of the generated revenues (DESIZE1) and in the second period in terms of the value of fixed assets (DESIZE2). Accordingly, Equation 2 
represents the empirical specification of the ideal model used for the analysis of firm market exit in Slovenia in the 1995-2000 period. Equation 3 shows the empirical specification of the ideal model for the 2000-2005 period.

$M E=f\left(\begin{array}{l}\text { INTE, INCE, INDSO, INDPO, INDP, INDIS, } \\ E X R O E, E X B E P, E X Q R, \\ D E F L, D E S I Z E 1, E N N A C E 2, E N R E G\end{array}\right)$
$M E=f\left(\begin{array}{l}\text { INTE, INCE, INDSO, INDPO, INDP, INDIS, } \\ \text { EXROA, EXROS, EXQR, } \\ D E F L, D E S I Z E 2, \text { ENNACE2, ENREG }\end{array}\right)$

Table 1 on the next page shows the results obtained from the logistic regression of the empirical specifications of the ideal market exit models for both studied periods. The models are estimated first for the 1995-2000 period and then for the 2000-2005 period. The results are

\section{Fig. 1: Selection of alternative non-nested models}

Step 1: Estimating Alternative 1

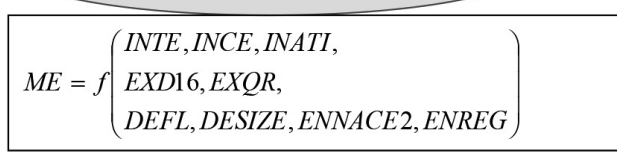

Step 2: Estimating Alternative 2

$M E=f\left(\begin{array}{l}I N T E, I N C E, I N A T I, \\ E X R R, E X P R, E X Q R, \\ D E F L, D E S I Z E, E N N A C E 2, E N R E G\end{array}\right)$

Step 4: Estimating Alternative 3

$$
M E=f\left(\begin{array}{l}
I N L P, I N C U, I N C T R, I N W, I N P C, I N A T I, \\
E X R R, E X P R, E X Q R, \\
D E F L, D E S I Z E, E N N A C E 2, E N R E G
\end{array}\right)
$$

\section{Step 3:}

Comparison

of Alternatives

1995-2000 2000-2005:

Alternative 2

1 and 2

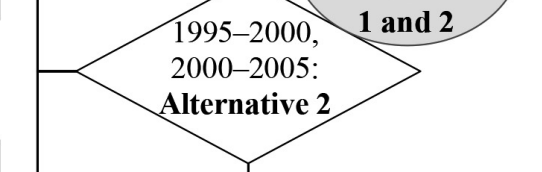

Step 5:

Comparison

2 and 3 1995-2000, 2 and 3 2000-2005:

Alternative 2

Source: own

shown in three columns for each of the analysed periods. The first depicts the results of the logit regression, the second the estimates obtained by the logit regression for rare events, and the third the estimates of the logit regression for rare events based on the empirical specification obtained with the backward elimination procedure that improves the model by dealing with the issue of multicollinearity [15].
The econometric tests presented in Table 1 confirm the statistical significance of all of the proposed econometric specifications regardless of the applied regression form. However, according to the $\mathrm{AIC}$ and $\mathrm{BIC}$ tests for both of the analysed periods the results of the logistic regression for rare events based on the backward elimination procedure outperform the other models. Still, they confirm the robustness of the regression coefficients we obtained. 


\section{Tab. 1: Results of the market exit models of Slovenian firms}

\begin{tabular}{l|c|c|c|c|c|c}
\multirow{2}{*}{$\begin{array}{c}\text { Dependent } \\
\text { variable ME }\end{array}$} & \multicolumn{3}{|c|}{$1995-2000$} & \multicolumn{3}{c}{ 2000-2005 } \\
\cline { 2 - 7 } & Logit & $\begin{array}{c}\text { Logit-rare } \\
\text { events }\end{array}$ & $\begin{array}{c}\text { Logit-rare events } \\
\text { (backward } \\
\text { elimination) }\end{array}$ & Logit & $\begin{array}{c}\text { Logit-rare } \\
\text { events }\end{array}$ & $\begin{array}{c}\text { Logit-rare events } \\
\text { (backward } \\
\text { elimination) }\end{array}$ \\
\hline INTE & -2.512 & -2.469 & & $-10.079^{\mathrm{a}}$ & $-10.920^{\mathrm{a}}$ & $-11.483^{\mathrm{a}}$ \\
\hline INCE & $-9.386^{\mathrm{a}}$ & $-9.322^{\mathrm{a}}$ & $-9.886^{\mathrm{a}}$ & 0.190 & -0.011 & \\
\hline INDSO & -0.001 & $0.001^{\mathrm{c}}$ & & 0.001 & 0.001 & \\
\hline INDPO & $0.016^{\mathrm{a}}$ & $0.015^{\mathrm{a}}$ & $0.016^{\mathrm{a}}$ & 0.010 & 0.009 & \\
\hline INDP & 0.203 & 0.203 & $0.245^{\mathrm{b}}$ & 0.052 & -0.042 & \\
\hline INDIS & $-0.016^{\mathrm{b}}$ & $-0.014^{\mathrm{c}}$ & $-0.015^{\mathrm{c}}$ & 0.001 & $-0.004^{\mathrm{a}}$ & \\
\hline
\end{tabular}

\begin{tabular}{l|c|c|c|c|c|c}
\hline EXQR & 0.004 & $0.008^{\mathrm{b}}$ & & 0.007 & 0.005 & 0.012 \\
\hline EXROE & $-11.343^{\mathrm{a}}$ & $-11.790^{\mathrm{a}}$ & $-11.372^{\mathrm{a}}$ & & & \\
\hline EXROA & & & & $-2.778^{\mathrm{a}}$ & $-2.709^{\mathrm{a}}$ & $-2.806^{\mathrm{a}}$ \\
\hline EXBEP & 0.001 & $0.028^{\mathrm{a}}$ & & & & \\
\hline EXROS & & & & -0.001 & -0.001 & \\
\hline
\end{tabular}

\begin{tabular}{l|c|c|l|c|c|c}
\hline DEFL & -0.003 & $0.003^{\mathrm{b}}$ & & $-7.8 \mathrm{E}-06$ & $-0.001^{\mathrm{a}}$ & \\
\hline DESIZE1 & $-3.7 \mathrm{E}-11$ & $1.2 \mathrm{E}-08$ & & & & \\
\hline DESIZE2 & & & & $-2.2 \mathrm{E}-10$ & $1.7 \mathrm{E}-08^{\mathrm{c}}$ & \\
\hline
\end{tabular}

\begin{tabular}{l|c|c|c|c|c|c}
\hline ENNACE2 dummy set & yes & yes & yes & yes & yes & yes \\
\hline ENREG dummy set & yes & yes & yes & yes & yes & yes \\
\hline Constant & $-3.297^{\mathrm{a}}$ & $-3.284^{\mathrm{a}}$ & $-3.651^{\mathrm{a}}$ & $-3.753^{\mathrm{a}}$ & $-3.728^{\mathrm{a}}$ & $-3.894^{\mathrm{a}}$ \\
\hline
\end{tabular}

\begin{tabular}{l|c|c|c|c}
\hline Log-likelihood & $-1,742.95$ & $-1,764.54$ & $-1,696.16$ & $-1,721.88$ \\
\hline LR $\chi 2$ & 237.04 & 193.87 & 260.51 & 209.06 \\
\hline AIC & $3,601.9$ & $3,551.1$ & $3,514.3$ & $3,463.8$ \\
\hline BIC & $4,046.1$ & $3,635.3$ & $3,986.3$ & $3,541.1$ \\
\hline p-value & 0.000 & 0.000 & 0.000 & 0.000 \\
\hline No. of observations & \multicolumn{2}{|c|}{15,647} \\
\hline
\end{tabular}

Note: $a, b$ and $c$ denote significance at $0.1 \%, 1 \%$ and $5 \%$, respectively

\section{Discussion and Conclusions}

The results confirm our hypothesis that technically and/or cost inefficient firms are more likely to exit the market. Namely, for both of the analysed periods the technical and cost efficiency regression coefficients have the expected negative sign. This confirms our main hypothesis that technical and cost efficiency are a decisive market exit factor. Considering our argument that technical and cost efficiency reflect the decisions made by the firm's management, our results confirm that management is one of the key factors in explaining firm market exit. Even though a firm's 
management plays many relevant roles within the firm, our research demonstrates that those management decisions that refer to input selection and their relative combinations are those which are most crucial for preventing a firm from failing and ensuring its survival.

The results also confirm our hypothesis that technical efficiency has a more significant influence on a firm's market exit compared to cost efficiency in a favourable macroeconomic environment, while cost efficiency has a more significant influence on a firm's market exit than technical efficiency in unfavourable macroeconomic conditions. It is evident from Table 1 that in the 1995-2000 period cost efficiency is a statistically significant firm market exit factor. This is not characteristic for technical efficiency in this period. Interestingly, the opposite holds true for the 2000-2005 period, when technically efficient firms were statistically significantly less likely to exit the market while cost efficiency did not have a significant impact. These results indicate that technical and cost efficiency reflect different internal market exit factors. Considering the definitions of cost and technical efficiency we could argue that in the first analysed period with tight macroeconomic conditions the market exit of Slovenian firms depended on either their allocative inefficiency or a combination of both their technical and allocative inefficiencies that are the two elements of cost efficiency. In this period, the market exit probability was thus impacted by management's decisions about the quantities and combinations of inputs relative to their prices. In the 2000-2005 period, i.e. the period of the consolidated market economy, the market exit probability depended mostly on the quantities of inputs employed and to a smaller degree on proper price-determined input combinations.

The latter results imply that during the period of the consolidated market economy those firms which exited the market were mostly technically inferior firms. Managers of such firms were able to influence the firm's cost level and allocate inputs according to relative input prices. However, they had limited influence on the technical efficiency due to obsolete techniques used in the firm's production. In the first period characterised by tight macroeconomic conditions managers also faced restrictions stemming from obsolete techniques. In addition, during this period management did not focus on properly allocating the inputs either because they were unable to do so or because incentives were not in place to stimulate such management decisions.

The conclusions have several important implications for both managers and policy makers. Results imply that in periods marked with unfavourable macroeconomic conditions managers make a serious mistake by ignoring input prices and delaying changes in the input mix in order to improve cost and price competitiveness through input substitution. In practice, input substitution is often associated with minor transaction costs. This implies that it can be achieved even if macroeconomic conditions are tight. In firms with technologies that limit input substitutability the managers unfortunately have hands tied making their firms more vulnerable, less adaptable and less capable of improving their competitiveness. In more stable macroeconomic circumstances, however, the most crucial changes that need to be implemented in firms are those that shift their production possibility frontier and not those that merely change the position of firms on the existing frontier. Implementing innovations and improving technical efficiency become key determinants of the firm's competitive position. Our research shows that in stable macroeconomic circumstances the survival of a firm that lags behind its competitors in this respect is put in jeopardy.

For policy makers our research is relevant because it shows that in times of unfavourable macroeconomic conditions interfering with relative input prices can have devastating consequences for many firms. Wrong or puzzling information about relative input prices created by price, monetary and income policies can mislead managers. Such interventions can create false information for managers and distort their decisions even to the extent that they result in firm failure. Economic policy should implement measures that lower the transaction costs associated with input substitution. Policies targeted at employment and labour market flexibility and measures aiming to support investment are of paramount importance in such circumstances. Policies aimed at encouraging innovation, however, should in such circumstances be expected to have smaller impacts because in unfavourable macroeconomic conditions managers often fail to identify the incentives and their effects. Such 
measures are thus more appropriate for times with stable macroeconomic conditions.

This paper draws from the doctoral dissertation research of Ksenja Pušnik. It is written in memory of Ksenja, who lost her battle against cancer at the beginning of 2011.

\section{References}

[1] AKAIKE, $H$. Information Theory and an Extension of the Likelihood Ratio Principle. In: PETROV, B.N., CSAKI, F. (Eds.). Proceedings of the Second International Symposium on Information Theory. Budapest: Akademinai Kiado, 1973. pp. 267-281. DOI:http://dx.doi. org/10.1007/978-1-4612-0919-5_38.

[2] APPETITI, S. Identifying Unsound Firms in Italy. An Attempt to Use Trend Variables. Journal of Banking and Finance. 1984, Vol. 8, Iss. 2, pp. 269-279. ISSN 0378-4266. DOI:http://dx.doi. org/10.1016/0378-4266(84)90007-4.

[3] ARISTOVNIK, A. Short-term Determinants of Current Account Deficits - Evidence from Eastern Europe and the Former Soviet Union. Eastern European Economics. 2008, Vol. 46, Iss. 1, pp. 24-42. ISSN 0012-8775. DOI:http:// dx.doi.org/10.2753/eee0012-8775460102.

[4] AUDRETSCH, D.B., MAHMOOD, T. New Firm Survival: New Results Using a Hazard Function. Review of Economics and Statistics. 1995, Vol. 77, Iss. 1, pp. 97-103. ISSN 00346535. DOI:http://dx.doi.org/10.2307/2109995.

[5] BAIN, J. Economies of Scale, Concentration and Entry. American Economic Review. 1954, Vol. 44, Iss. 1, pp. 15-39. ISSN 0002-8282.

[6] BARNEY, J. Firm Resources and Sustained Competitive Advantage. Journal of Management. 1991, Vol. 17, Iss. 1, pp. 99-120. ISSN 0149-2063. DOI:http://dx.doi. org/10.1177/014920639101700108.

[7] BARR, R., SEIFORD, L. and SIEMS, T. An Envelopment Analysis Approach to Measuring the Managerial Efficiency of Banks. Annals of Operations Research. 1993, Vol. 45, Iss. 1, pp. 1-15. ISSN 0254-5330. DOI:http://dx.doi. org/10.1007/bf02282039.

[8] BECCHETTI, L. and SIERRA, J. Bankruptcy Risk and Productive Efficiency in Manufacturing Companies. Journal of Banking and Finance. 2003, Vol. 27, Iss. 11, pp. 2099-2120. ISSN 0378-4266. DOI:http://dx.doi.org/10.1016/ s0378-4266(02)00319-9.

[9] BHATTACHARJEE, A., HIGSON, C., HOLLY, S. and KATTUMAN, P. Macroeconomic
Instability and Business Exit: Determinants of Failures and Acquisitions of Large UK Firms. Economica. 2009, Vol. 76, Iss. 301, pp. 108-131. ISSN 0013-0427. DOI:http://dx.doi. org/10.1111/j.1468-0335.2007.00662.x.

[10] BHATTACHARJEE, A., HIGSON, C., HOLLY, S., KATTUMAN, P. Business Failure in UK and US Quoted Firms: Impact of Macroeconomic Instability and the Role of Legal Institutions. Cambridge Working Papers in Economics: 0420. Cambridge: Faculty of Economics, University of Cambridge, 2004.

[11] BREZIGAR-MASTEN, A., MASTEN, I. Comparison of Parametric, Semi-Parametric and Non-Parametric Methods in Bankruptcy Prediction. IMAD Working Paper Series: 6/2009. Ljubljana: IMAD, 2009.

[12] BRÜDERL, J. and SCHÜSSLER, R. Organizational Mortality: The Liabilities of Newness and Adolescence. Administrative Science Quarterly. 1990, Vol. 35, Iss. 4, pp. 530-547. ISSN 0001-8392. DOI:http://dx.doi. org/10.2307/2393316.

[13] CARROLL, G.R. A Stochastic Model of Organizational Mortality: Review and Analysis. Social Science Research. 1983, Vol. 12, Iss. 4, pp. 303-329. ISSN 0049-089X. DOI:http:// dx.doi.org/10.1016/0049-089x(83)90022-4.

[14] CEFIS, E. and MARSILI, O. A Matter of Life and Death: Innovation and Firm Survival. LEM Papers Series: 2005/01. Pisa: Laboratory of Economics and Management, 2005. DOI:http:// dx.doi.org/10.1093/icc/dth081.

[15] CHATTERJEE, S. and HADI, A.S. Regression Analysis by Example. 4th ed. New York: John Wiley and Sons, 2006. ISBN 978-0-470-05545-8. DOI:http://dx.doi. org/10.1002/0470055464.

[16] CHURCHILL, N. and LEWIS, V. The Five Stages of Small Business Growth. Harvard Business Review. 1983, Vol. 61, Iss. May-June, pp. 30-50. ISSN 0017-8012.

[17] CIELEN, A., PEETERS, L., VANHOOF, K. Bankruptcy Prediction Using a Data Envelopment Analysis. European Journal of Operational Research. 2004, Vol. 154, Iss. 2, pp. 526-532. ISSN 0377-2217. DOI:http://dx.doi. org/10.1016/s0377-2217(03)00186-3.

[18] CLARKE, K.A. Nonparametric Model Discrimination in International Relations. Journal of Conflict Resolution. 2003, Vol. 47, Iss. 1, pp. 72-93. ISSN 0022-0027. DOI:http:// dx.doi.org/10.1177/0022002702239512.

[19] COASE, R. The Nature of the Firm. 
Economica. 1937, Vol. 4, Iss. 16, pp. 386405. ISSN 0013-0427. DOI:http://dx.doi. org/10.1111/j.1468-0335.1937.tb00002.x.

[20] COUCKE, K. and SLEUWAEGEN, L. Offshoring as a Survival Strategy: Evidence from Manufacturing Firms in Belgium. Journal of International Business Studies. 2008, Vol. 39, Iss. 8, pp. 1261-1277. ISSN 0047-2506. DOI: http://dx.doi.org/10.1057/palgrave.jibs.8400403. [21] CYBINSKI, P.J. and FORSTER, J. The Macroeconomic Environment and the Process of Business Failure: Explorations with US Firms in an Economically Volatile Period, 19741988. International Journal of Business and Economics. 2002, Vol. 2, Iss. 1, pp. 13-23. ISSN 1543-1614.

[22] DENIS, D.J. and DENIS, D.K. Causes of Financial distress Following Leveraged Capitalizations. Journal of Financial Economics. 1995, Vol. 37, Iss. 2, pp. 129-157. ISSN 0304405X. DOI:http://dx.doi.org/10.1016/0304405x(94)00792-y.

[23] DUNNE, P. and HUGHES, A. Age, Size, Growth and Survival: UK Companies in the 1980s. Journal of Industrial Economics. 1994, Vol. 42, Iss. 2, pp. 115-137. ISSN 0022-1821. DOI:http://dx.doi.org/10.2307/2950485.

[24] ERICSON, R. and PAKES, A. MarkovPerfect Industry Dynamics: A Framework for Empirical Work. Review of Economic Studies. 1995, Vol. 62, Iss. 1, pp. 53-82. ISSN 00346527. DOI:http://dx.doi.org/10.2307/2297841.

[25] FARRELL, M.J. The Measurement of Productive Efficiency. Journal of the Royal Statistical Society. 1957, Vol. 120, Iss. 3, pp. 253-281. ISSN 0035-9238. DOI:http://dx.doi. org/10.2307/2343100.

[26] FOREMAN, R.D. A Logistic Analysis of Bankruptcy within the US Local Telecommunications Industry. Journal of Economics and Business. 2003, Vol. 55, Iss. 2, pp. 135-166. ISSN 0148-6195. DOI:http:// dx.doi.org/10.1016/s0148-6195(02)00133-9.

[27] FOTOPOULOS, G. and LOURI, $H$. Location and Survival of New Entry. Small Business Economics. 2000, Vol. 14, Iss. 4, pp. 311-321. ISSN 0921-898X. DOI:http://dx.doi. org/10.1023/a:1008180522759.

[28] FREEMAN, J., CARROLL, G.R. and HANNAN, M.T. The Liability of Newness: Age Dependence in Organizational Death Rates. American Sociological Review. 1983, Vol. 48, pp. 692-710. ISSN 0003-1224. DOI:http:// dx.doi.org/10.2307/2094928.
[29] FRIED, H.O., LOVELL, C.A.K. and SCHMIDT, S.S. The Measurement of Productive Efficiency and Productivity Change. Oxford: Oxford University Press, 2008. ISBN 9780195183528. DOI:http://dx.doi.org/10.1093/ acprof:oso/9780195183528.001.0001.

[30] GIBRAT, R. Les Inegalites Economiques. Paris: Librairie du Recueil Sirey, 1931.

[31] HARRIS, R.I.D. and LI, Q.C. Export-Market Dynamics and the Probability of Firm Closure: Evidence for the United Kingdom. Scottish Journal of Political Economy. 2010, Vol. 57, Iss. 2, pp. 145-168. ISSN 0036-9292. DOI:http:// dx.doi.org/10.1111/j.1467-9485.2010.00511.x. [32] JOVANOVIC, B. Selection and the Evolution of Industry. Econometrica. 1982, Vol. 50, pp. 649-670. ISSN 0012-9682. DOI:http:// dx.doi.org/10.2307/1912606.

[33] JOVANOVIC, B. Firm Formation with Heterogeneous Management and Labor Skills. Small Business Economics. 1994, Vol. 6, Iss. 3, pp. 185-192. ISSN 0921-898X. DOI:http:// dx.doi.org/10.1007/bf01108287.

[34] KAO, C. and LIU, S. Predicting Bank Performance with Financial Forecasts: A Case of Taiwan Commercial Banks. Journal of Banking and Finance. 2004, Vol. 28, Iss. 10, pp. 2353-2368. ISSN 0378-4266. DOI:http://dx.doi. org/10.1016/j.jbankfin.2003.09.008.

[35] KING, G. and ZENG, L. Logistic Regression in Rare Events Data. Political Analysis. 2001, Vol. 9, Iss. 2, pp. 137-163. ISSN 1047-1987. DOI:http://dx.doi.org/10.1093/oxfordjournals. pan.a004868.

[36] KÖKE, J. Determinants of Acquisition and Failure: Evidence from Corporate Germany. Structural Change and Economic Dynamics. 2002, Vol. 13, Iss. 4, pp. 457-484. ISSN 0954349X. DOI:http://dx.doi.org/10.1016/s0954349x(02)00024-3.

[37] LUSSIER, R. A Startup Business Success versus Failure Prediction Model for the Retail Industry. The Mid-Atlantic Journal of Business. 1996, Vol. 32, Iss. 2, pp. 79-92. ISSN 0732-9334. [38] NUCCI, A.R. The Demography of Business Closings. Small Business Economics. 1999, Vol. 12, Iss. 1, pp. 25-39. ISSN 0921-898X.DOI:http:// dx.doi.org/10.1023/a:1008036821487.

[39] OPLER, T. and TITMAN, S. Financial Distress and Corporate Performance. Journal of Finance. 1994, Vol. 49, Iss. 3, pp. 10151040. ISSN 0022-1082. DOI:http://dx.doi. org/10.1111/j.1540-6261.1994.tb00086.x.

[40] PANZAR, J. Determinants of Firm and 
Industrial Structure. In: SCHMALENSEE, E., WILLING, R. (eds.). Handbook of Industrial Organization. North-Holland: Elsevier, 1989. pp. 3-59. DOl:http://dx.doi.org/10.1016/s1573448x(89)01004-6.

[41] PARADI, J.C., ASMILD, M. and SIMAK, M.C. Using DEA and Worst Practice DEA in Credit Risk Evaluation. Journal of Productivity Analysis. 2004, Vol. 21, Iss. 2, pp. 153-156. ISSN 0895-562X. DOI:http://dx.doi.org/10.1023/ b:prod.0000016870.47060.0b.

[42] PENROSE, E.T. The Theory of the Growth of the Firm. New York: M. E. Sharpe, 1959. ISBN 978-0-19-828977-7. DOI:http://dx.doi. org/10.2307/3111440.

[43] PHILLIPS, B. and KIRCHHOFF, B.A. Formation, Growth and Survival; Small Firm Dynamics in the US Economy. Small Business Economics. 1989, Vol. 1, Iss. 1, pp. 65-74. ISSN 0921-898X. DOI:http://dx.doi.org/10.1007/ bf00389917.

[44] PILLE, P. and PARADI, J.C. Financial Performance Analysis of Ontario (Canada) Credit Unions: An Application of DEA in the Regulatory Environment. European Journal of Operational Research. 2002, Vol. 139, Iss. 1/2, pp. 339-350. ISSN 0377-2217. DOI:http:// dx.doi.org/10.1016/s0377-2217(01)00359-9.

[45] POMPE, P. and BILDERBEEK, J. The Prediction of Bankruptcy of Small- and Medium-Sized Industrial Firms. Journal of Business Venturing. 2005, Vol. 20, Iss. 6, pp. 847-868. ISSN 0883-9026. DOI:http://dx.doi. org/10.1016/j.jbusvent.2004.07.003.

[46] PREMACHANDRA, I.M., BHABRA, G.S. and SUEYOSHI, T.DEA as a Tool for Bankruptcy Assessment: A Comparative Study with Logistic Regression Technique. European Journal of Operational Research. 2009, Vol. 193, Iss. 2, pp. 412-424. ISSN 0377-2217. DOI:http://dx.doi. org/10.1016/j.ejor.2007.11.036.

[47] PSILLAKI, M., TSOLAS, I.E. and MARGARITIS, D. Evaluation of Credit Risk Based on Firm Performance. European Journal of Operational Research. 2010, Vol. 201, Iss. 3, pp. 873-881. ISSN 0377-2217. DOI:http:// dx.doi.org/10.1016/j.ejor.2009.03.032.

[48] PUŠNIK, K. Dejavniki izstopa podjetij s trga na primeru Slovenije (Determinants of Firm Market Exit in the Case of Slovenia). Doctoral Dissertation. Ljubljana: Ekonomska fakulteta, 2008.

[49] PUŠNIK, K. and TAJNIKAR, M. Technical and Cost Efficiencies as Determinants of Business Failures of Small Firms: The Case of Slovenia. Eastern European Economics. 2008, Vol. 46, Iss. 1, pp. 45-64. ISSN 00128775. DOI:http://dx.doi.org/10.2753/eee00128775460103.

[50] RAFTERY, A.E. Bayesian Model Selection in Social Research. In: MARSDEN, P.V. (ed.). Sociological Methodology. Oxford: Blackwell, 1995. pp. 111-163. DOI:http://dx.doi. org/10.2307/271063.

[51] SCHUMPETER, J.A. The Theory of Economic Development. An Inquiry into Profits, Capital, Credit, Interest, and the Business Cycle. Cambridge: Harvard University Press, 1934. ISBN 0691042535.

[52] SHLEIFER, A. and VISHNY, R.W. Liquidation Value and Debt Capacity: A Market Equilibrium Approach. Journal of Finance. 1992, Vol. 47, Iss. 4, pp. 1343-1366. ISSN 00221082. DOI:http://dx.doi.org/10.2307/2328943.

[53] TAJNIKAR, M. Transitional Adjustment of Large Companies in Slovenia and Economic Policy. Post-Communist Economies. 2001, Vol. 13, Iss. 3, pp. 331344. ISSN 1463-1377. DOI:http://dx.doi. org/10.1080/14631370120074867.

[54] TAJNIKAR, M. and PUŠNIK, K. The Effect of Technical and Cost Efficiency on the Income Position of Firms in Tourism. In: GALETIĆ, L., ČAVLEK, N. (eds.). An Enterprise Odyssey: Tourism - Governance and Entrepreneurship Proceedings. Zagreb: Faculty of Economics and Business, 2008. pp. 201-202.

[55] THORNHILL, S. and AMIT, R. Learning about Failure: Bankruptcy, Firm Age and the Resource-Based View. Organization Science. 2003, Vol. 15, Iss. 5, pp. 497-509. ISSN 1047-7039. DOI:http://dx.doi.org/10.1287/ orsc.14.5.497.16761.

[56] TSIONAS, E.G. and PAPADOGONAS, T.A. Firm Exit and Technical Inefficiency. Empirical Economics. 2006, Vol. 31, pp. 535-548. ISSN 0377-7332. DOI:http://dx.doi.org/10.1007/ s00181-005-0045-2.

[57] VUONG, Q. Likelihood Ratio Tests for Model Selection and Non-Nested Hypotheses. Econometrica. 1989, Vol. 57, Iss. 2, pp. 307333. ISSN 0012-9682. DOI:http://dx.doi. org/10.2307/1912557.

[58] WATSON, J. and EVERTT, J.E. Do Small Businesses Have High Failure Rates? Journal of Small Business Management. 1996, Vol. 34, Iss. 4, pp. 45-52. ISSN 0047-2778.

[59] WHEELOCK, D.C. and WILSON, P.W. Why Do Banks Disappear? The Determinants of US 
Bank Failures and Acquisitions. The Review of Economics and Statistics. 2000, Vol. 82, Iss. 1, pp. 127-138. ISSN 0034-6535. DOl:http:// dx.doi.org/10.1162/003465300558560.

[60] WILLIAMS, M. Measuring Business Starts, Success and Survival: Some Database Considerations. Journal of Business Venturing. 1993, Vol. 8, Iss. 4, pp. 295-299. ISSN 08839026. DOI:http://dx.doi.org/10.1016/08839026(93)90001-I.

[61] WILLIAMSON, O.E. The Economic Institutions of Capitalism. New York: Free Press, 1985. ISBN 0-02-934820-X.

[62] YEH, O.J. The Application of Data Envelopment Analysis in Conjunction with Financial Ratios for Bank Performance Evaluation. Journal of the Operational Research Society. 1996, Vol. 47, Iss. 8, pp. 980-988. ISSN 0160-5682. DOI:http://dx.doi. org/10.2307/3010406.

[63] ZAJC KEJŽAR, K. The Role of Foreign Direct Investment in the Host-Country Firm Selection Process: Firm-Level Evidence from Slovenian Manufacturing. Review of World
Economics. 2011, Vol. 147, Iss. 1, pp. 169-193. ISSN 1610-2886. DOI:http://dx.doi.org/10.1007/ s10290-010-0077-3.

Petra Došenović Bonča, PhD

University of Ljubljana

Faculty of Economics petra.d.bonca@ef.uni-lj.si

Nina Ponikvar, PhD University of Ljubljana Faculty of Economics nina.ponivar@ef.uni-lj.si

Ksenja Pušnik, PhD

University of Maribor

Faculty of Economics and Business

Maks Tajnikar, PhD

University of Ljubljana

Faculty of Economics maks.tajnikar@ef.uni-lj.si 


\section{Abstract}

\section{THE ROLE OF MANAGEMENT DECISIONS IN EXPLAINING FIRM MARKET EXIT}

Petra Došenović Bonča, Nina Ponikvar, Ksenja Pušnik, Maks Tajnikar

We study factors of firm market exit and focus on the role of the firm's management. We assume that the quality of decisions made by the firm's management can be assessed by the firm's technical and cost efficiency levels. We argue that the decisions of management are an important determinant of firm market exit and hypothesise that the characteristics of the macroeconomic environment influence the impact of technical and cost efficiency on firm market exit. This is why we study whether the importance of decisions that are relevant for attaining technical efficiency and decisions that contribute to cost efficiency for firm market exit depend on the macroeconomic environment of the analysed firms. Such an analysis reveals which types of managerial decisions are relevant for firm market exit in differing macroeconomic environments. We use a logistic regression for rare events to estimate non-nested microeconomic models of firm market exit in Slovenia for two periods characterised by differing macroeconomic conditions. The results confirm that firms in which decisions of management result in inferior efficiency are more likely to exit the market. Even though a firm's management plays many relevant roles within the firm, our research demonstrates that those management decisions that refer to input selection and their substitution are those which are most crucial for preventing a firm from failing and ensuring its survival. We also find that in differing macroeconomic environments different types of management decisions explain firm market exit. The results show that technical efficiency has a more significant influence on a firm's market exit compared to cost efficiency in a favourable macroeconomic environment, while cost efficiency has a more significant influence on a firm's market exit than technical efficiency in unfavourable macroeconomic conditions.

Key Words: Market exit, management's decisions, non-nested microeconomic models, Slovenia.

JEL Classification: L10.

DOI: 10.15240/tul/001/2015-2-008 